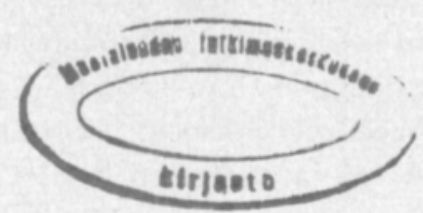

\title{
Suomen Maataloustieteellisen Seuran toiminnasta vuosina $1909-1972$
}

\author{
Marja-Leena Puntila, tiedotussihteeri
}

\section{Activities of the Scientific Agricultural Society of Finland from 1909 to 1972}

\author{
Marja-Lenna Puntila, Public Relations Secretary
}

\begin{abstract}
The Scientilic Agricultural Society of Finland was founded in 1909 in order to promote agricultural research in Finland and to make this activity known at home and abroad. By 1972 the Society's membership had risen to over 400 members.

An essential part of the Society's activities has consisted of meetings with lectures. In the six or seven meetings arranged annually the Society has heard in addition to Finnish research workers a number of visiting lecturers.

In 1911 the Society inaugurated two series of publications: ${ }^{2}$ Publications of the Scientific Agricultural Society of Finland and Abhandlungen der Agrikulturwissenschaftlichen Gesellschaft in Finnlands. The former consisted of short summaries of research papers, lectures and information from the meetings, minutes of the meetings as well as annual reports and audits. The actual research papers were published in German in the latter publication.

In 1928 the name of the German series was changed to Acta Agralia Fennica and as publication languages were chosen English, German, Swedish and Finnish. In 1929 the Society began the regular publication in English of the Journal of the Scientific Agricultural Society of Finlands. By the end of 1972, 129 issues had been published of the Acta Agralia Fennica. The number of published annual volumes of the Journal was 44 , each volume consisting of four journals.

At the beginning of 1973 the two publications were merged to form one comprehensive series under the name Journal of the Scientific Agricultural Society of Finlands. Each annual volume consists of $500-600$ printed pages, the average number of issues being six, or minimum four, issues.

The Library of the Scientific Agricultural Society of Finland is connected with the Agricultural Library of the University of Helsinki. In 1972 the Library had connections on an exchange basis with libraries in 43 countries.
\end{abstract}

\section{Johdanto}

Suomen Maataloustieteellisen Seuran perustamisesta oli kulunut 60 vuotta joulukuun 2 pnä 1969. Yhteenvetoa seuran toiminnasta ei ole kirjoitettu vuoden 1934 jälkeen. Historiikin laatiminen seuran 60-vuotisesta toiminnasta lykkääntyi eri syistä johtuen aina vuoden 1973 alkuun asti. Seuran hallitus piti 
sopivana ajankohtana sen julkaisemiseksi vaihetta, jolloin seuran julkaisusarjat sulautettiin yhteen. Kirjoittamistehtävä annettiin seuran tiedotussihteerille.

Historiikissä käsitellään ensin lyhyesti ensimmäistä 25-vuotisjaksoa kokonaiskuvan saamiseksi seuran toiminnan eri vaiheista. Huomattavasti laajemmin ja yksityiskohtaisemmin kuvataan vuosia 1935-72. Tältä ajalta on katsaus jaettu kolmeen eri jaksoon. Ensimmäinen käsittää vuodet 1935-49, toinen vuodet $1950-59$ ja viimeinen vuodet $1960-72$.

\section{Vuodet $1909-34$}

Selostus ensimmäisestä 25-vuotisesta toimintakaudesta perustuu J. E. Aalto-Setälän kirjoitukseen "Kertomus Suomen Maataloustieteellisen Seuran 25-vuotisesta toiminnasta" (Acta Agralia Fennica no 31, 1934).

Korkeimman maatalousopetuksen siirtäminen Mustialasta Helsingin Yliopistoon 1900-luvun alussa oli omiaan vilkastuttamaan maataloustieteellistä toimintaa maamme pääkaupungissa. Paitsi yliopistossa ja silloisessa Maanviljelystaloudellisessa Koelaitoksessa tapahtuvaa tutkimustyötä, kaivattiin sitä myös vapaan tieteellisen järjestön suorittamana. Tätä varten suunniteltiin erikoista maataloustiedemiesten akatemiaa, joka olisi työskennellyt lähinnä Ruotsin Kungliga Lantbruks-Akademien tapaan. Suunnitelmasta ei kuitenkaan tullut mitään, sillä varsinkaan metsämiehet eivät halunneet alistua tällaisen akatemian alaosastoksi, vaan vaativat itsenäisempää toimintamuotoa.

Keväällä 1909 heräsi eräässä suppeassa, ensisijaisesti maanviljelystaloudellista tutkimusta harrastavassa piirissä ajatus sellaisen seuran perustamisesta, jonka tarkoituksena olisi saada käyntiin maamme maanviljelystaloudellisten olojen tutkiminen ja selvittäminen. Tällöin lähdettiin siitä käsityksestä, että maanviljelystaloudellinen tutkimustyö on välttämätön objektiivisen perustan luomiseksi maataloutemme tilan oikealle arvostelemiselle yhtä hyvin yksityiskuin yleistaloudelliselta kannalta. Tällä alalla harjoitettu tutkimus olisi omiaan suuressa määrin lisäämään maatalouden edistämistä tarkoittavien toimenpiteiden tarkoituksenmukaisuutta ja tehokkuutta. Saman vuoden syksyllä ryhdyttiin seuran perustamista harkitsemaan lähemmin ja asiasta keskusteltiin sellaisten henkilöiden kanssa, jotka olivat tämän alkuaan varsin suppean piirin ulkopuolella. Tällöin heräsi epäilyksiä siitä, olisiko meillä tällä erikoisalalla toistaiseksi riittävästi työvoimaa seuran menestykselliselle toiminnalle. Tämä johtikin laajemmalla pohjalla olevan seuran perustamisajatukseen. Tarkoituksena oli luoda sellainen seura, joka pyrkisi kokoamaan yhteen kaikkien maataloustieteiden alat ja lisäksi liittämään yhteiseen työhön tutkijoita maataloutta lähellä olevien tieteiden aloilta.

Maataloustieteellinen Seura - Lantbruksvetenskapliga Samfundet i Finland perustettiin joulukuun 2 pnä 1909. Perustavassa kokouksessa kahdestakymmenestä läsnäolleesta henkilöstä on tällä hetkellä elossa ainoastaan professori Rurik Pihkala, silloinen maisteri. Perustajajäsenten joukossa on mm. ollut entinen presidenttimme Lauri Kr. Relander.

Seuran tavoitteena tuli olemaan kotimaisella pohjalla tehdyn maataloudellisen tutkimustyön edistäminen ja kannattaminen. Sen tuli koota yhteen 
hyvinkin hajallaan olevat silloiset maamme tutkijavoimat ja herättää harrastusta tutkimustyöhön. Sen tuli luoda yhdysside maataloudellisen tutkimuksen ja sen lähitieteiden alalla toimivien tutkijain kesken, kuten myös koti- ja ulkomaisen maataloudellisen tutkimustyön välille. Sen tuli aloittaa kaivatun julkaisusarjan toimittaminen, jotta tutkimustulokset olisi voitu julkaista yhteen kerättyinä.

Seuran perustamisesta päätettiin yksimielisesti, vaikkakin oli epäilyksiä seuran toimintamahdollisuuksista vähäisen jäsenmäärän takia. Luotettiin kuitenkin olosuhteiden muuttumiseen. Seuran ensimmäiseksi puheenjohtajaksi valittiin professori Arthur Rindell.

Seuran ensimmäisissä säännöissä mainitaan seuran tarkoituksena olevan ei ainoastaan edistää ja kannattaa maatalouden eri alojen tutkimustyötä, vaan toimittaa myös julkaisuja, järjestää kokouksia esitelmineen, tiedonantoineen ja keskusteluineen, toimeenpanna tiedusteluja, avustaa tutkimuksia ja kokeita sekä jakaa stipendejä ja pitää yllä yhteistoimintaa vastaavanlaisten kotimaisten ja ulkomaisten tieteellisten seurojen kanssa. Nämä muodostivatkin seuran pääasiallisimman toimintakentän sen alkuaikoina.

Sen aikainen tutkimustyö liikkui melkoisen avarissa puitteissa. Maaperäopilliset tutkimukset olivat varsin intensiivisiä ja niistä, samoin kuin kasvinviljelyä koskevista tutkimuksista, pidettiin lukuisia esityksiä seuran kokouksissa. Mainitaan varsinkin kasvien ravitsemus- ja lannoituskysymysten olleen erittäin vilkkaan mielenkịinnon kohteina. Myöskin maatalouskoneet saivat osakseen huomiota. Ravițsemusfysiologia näytteli pääosaa kotieläintieteen puolella. Kotimaisen lypsykarjan jalostus ja perinnölliset ilmiöt olivat esillä kotieläinten jalostustutkimuksissa. Eläinlääketiede selvitteli kulkutautien; nautatuberkuloosin ja hevosinfluenssan esiintymistä maassamme. Huomattava sija seuran harrastuspiirissä oli maanviljelystaloudellisilla ja maatalouspoliittisilla kysymyksillä. Ensisijaisesti voisi mainita maatalouden kannattavuustutkimukset ja niihin liittyvät tuotantokustannuksia käsittelevät aiheet. Maatalouspoliittisissa esityksissä on seuran kokouksissa käsitelty mm. uusinta jakolainsäädäntöä, maaverotusta, valtion maiden asuttamista jne.

Vuodesta 1911 lähtien seura alkoi toimittaa kahta julkaisusarjaa, joista toisen nimenä oli Suomen Maataloustieteellisen Seuran Julkaisuja ja toisen Abhandlungen der Agrikulturwissenschaftlichen Gesellschaft in Finnland. Edellisessä julkaistiin lyhennelmiä tutkimustuloksista, seuran kokouksissa pidettyjä esitelmiä, tiedonantoja ja alustuksia, seuran kokousten pöytäkirjat sekä vuosija tilikertomukset. Varsinaiset tutkimukset julkaistiin saksankielellä jälkimmäisessä sarjassa.

Julkaisusarjojen toimittamisen tavoitteena pidettiin tutkimusțulosten julkistamista ja yhteyksien luomista tutkimuksen ja käytännön välille. Seuralla oli tässä työssään koettavana monia vaikeuksia, joista ennen kaikkea on mainittava varojen puute. Tilanne parantui, kun osa julkaisuista voitiin painattaa ilmaiseksi Valtioneuvoston kirjapainossa v. 1915-24. Lukuisat liikkeet, luottolaitokset, säätiöt ja yksityiset henkilöt avustivat rahallisesti tutkimustyötä kaikkein kiperimpinä aikoina.

Ensimmäisen maailmansodan aika löi leimansa myös Maataloustieteellisen Seuran toimintaan. Tällöin tuli mm. kielto tutkimuksien painattamisesta sak- 
san kielellä. Tämän seurauksena yhteydet ulkomaihin vaikeutuivat. Varojen puutteessa ei seura alkuvuosina myöskään pystynyt jakamaan avustuksia ja stipendejä. Tämä vaikeutti laajempien tutkimusten alullesaattamista.

Tri E. Cajander on kirjoituksessaan ensimmäiseltä 10-vuotisjaksolta maininnut mm. seuraavaa: „Seuran toiminta on suureksi osaksi ollut ensimmäisten peltotilkkujen raivaamista. Toiminta on ollut tieteellistä, mutta päämäärä on kuitenkin käytännöllinen. Käytännön maanviljelijöiden piireissä on alkanut vakiintua se käsitys, että käytännöllisen maataloustoiminnan perustana on tieteellinen työ, siis tieteen ja käytännön käydessä käsi kädessä saavutetaan maataloudessa parhaat tulokset."

Seuraavan 10-vuotistaipaleen tapahtumista voisi lyhyesti mainita joitakin yksityiskohtia.

Maassamme aloitettiin Maatalousviikon viettäminen. Seura osallistui siihen kokouksellaan. Kasvinviljelykoetoiminnan järjestäminen maassamme tuli keskustelun alaiseksi. Tutkimusapurahojen saanti helpottui. Seuran kirjaston perustaminen tuli ajankohtaiseksi.

Ehdotus säännöllisesti ilmestyvän ammatillisen julkaisun aikaansaamisesta tehtiin v. 1922, mutta vasta v. 1929 alusta Maataloustieteellinen Aikakauskirja alkoi ilmestyä. Abhandlungen-sarjaan hyväksytyt tutkimukset päätettiin julkaista joko jollakin eurooppalaisista sivistyskielistä tai jommallakummalla kotimaisella kielellä. Abhandlungen-sarjan nimi mutettiin v. 1928 Suomen Maataloustieteellisen Seuran Julkaisuja - Acta Agralia Fennica-nimiseksi. 1920-luvun lopulla saatiin täydellinen aakkosellinen korttiluettelo kaikesta suomenkielisestä maataloutta ja sen sivuelinkeinoja käsittelevästä kirjallisuudesta vuosilta $1542-1920$, ja toinen laaja luettelo Suomea koskevasta ruotsintai muunkielisestä maatalouskirjallisuudesta vuosilta $1886-1921$.

Raha-asiat saatiin parempaan kunțoon, kun Valtioneuvosto myönsi seuralle säännöllisen valtionavustuksen lisäksi tietyn summan raha-arpajaisten voittovaroista. Kuitenkin pula-ajan vaikutus tuntui valtionavustuksen pienenemisenä 1930-luvun alussa. Pari vuotta myöhemmin päätettiin jäseniltä kantaa jäsenmaksua, jota vastaan jäsenet saivat seuran kaikki julkaisut. Seuran kasvinviljely- ja kasvibiologinen osasto perustettiin v. 1933.

Seuran neljännesvuosisadan toiminta loi suunnan ja perustan, jolta oli hyvä lähteä eteenpäin. Valtiovalta oli yleensä suhtautunut seuran pyrkimyksiin suopeasti. Ilman valtion tukea sen toiminta olisikin jäänyt merkitykseltään vähäiseksi.

\section{Vuodet $1935-49$}

Seuran julkaisutoiminta vilkastui, kun saatiin runsaammin käyttövaroja. Kokouksista ryhdyttiin ilmoittamaan paitsi kirjeitse myös muutamissa suurimmissa päivälehdissä. Keskusteltiin koe- ja tukimuslaitoksen tarpeellisuudesta Pohjois-Suomen olojen tutkimista silmälläpitäen.

Johtokunta harkitsi uuden julkaisusarjan perustamista, johon otettaisiin maataloutta koskevia komiteamietintöjä ja selvittelyjä, mutta sarjaa ei kuitenkaan ryhdytty julkaisemaan. 
Vuoden 1938 alusta seura lakkautti jäsenmaksujen kannon. Samana vuonna seura päätti liittyä kansainvälisen maataloustutkijain yhdistyksen jäseneksi. Katsottiin, että yhteydenpito vuosittain Cambridgessä pidettäviin Agricultural Economics Societyn kokouksiin saattaisi olla hyödyksi myös maamme maataloustuotteiden viennin ja yleensäkin Englannin ja Suomen välisen maataloutta koskevan kaupan kannalta. Vuonna 1939 seura sai Suomen Kulttuurirahastolta 100000 markan suuruisen tutkimusapurahan sellaisten rehunviljelystä koskevien tutkimusten edistämiseksi, jotka tähtäävät valkuaisrikkaiden ostoväkirehujen korvaamiseen kotimaisilla rehuilla. Saman vuoden syksyllä alkanut Euroopan sotaisten selkkausten sarja tyrehdytti seurankin toiminnan kokonaan. Välirauhan aikana olot olivat siinä määrin epäsäännölliset, ettei seuran koollekutsumista voitu ajatella. Sääntöjen mukaan helmikuussa pidettäväksi määrätty vuosikokous voitiin vuonna 1940 kutsua koolle vasta toukokuussa. Syksyllä toiminta kuitenkin normalisoitui ja jäsenet olivat runsaslukuisina mukana seuran kokouksissa. Vuosien $1942-45$ toiminta jäi myös sodan johdosta vaatimattomaksi kohdistuen pääasiassa julkaisutoimintaan. Pöytäkirjoissa mainitaan sodan vaikutuksen tuntuneen vielä v. $1946-47$, mutta toimintavuonna $1947-$ 48 on kokoustoiminta ollut jo varsin vilkasta. Kokouksissa pidettiin useita merkittäviä esitelmiä, kuten professori A. I. Virtasen esitelmä »AIV-menetelmä karjanruokinnan perustana». Professori Virtanen oli kehittämästään menetelmästä saanut vuoden 1945 kemian Nobel-palkinnon. Seuran tilaisuuksissa on myös kuultu lukuisia ulkomaisia esitelmöitsijöitä.

Kauan vireillä ollut maataloussanakirjan toimittaminen aloitettiin vuonna 1948. Tämän vaativan työn suoritti maisteri Liisa Mali.

Seuran 40-vuotisjuhlakokous järjestettiin 2.12.1949 Yliopiston pienessä juhlasalissa. Juhlassa pitämässään tervehdyspuheessa seuran silloinen puheenjohtaja, nykyinen kunniajäsen professori E. A. Jamalainen, totesi maataloudellisen tutkimustyön saavuttaneen laajat mittasuhteet. Tutkimustyö oli huomattavasti muuttanut luonnettaan siitä, mitä se oli 40 vuotta aikaisemmin. Entistä enemmän oli alettu erikoistua. Tutkimusaiheiden todettiin lisääntyneen $\mathrm{mm}$. kemian alalla, ja erilaisten kemiallisten aineiden käyttö oli saavuttanut yhä suuremman merkityksen maataloudessa. Maataloustuotannon parantamiseen ja lisäämiseen oli tutkimustyöllä voitu ratkaisevasti vaikuttaa. Puhuja korosti, että tuotannon kasvun myötä oli yhä enenevässä määrin kiinnitettävä huomiota kasvi- ja eläinkunnasta saatujen tuotteiden laatuun. Epäkohtana puhuja piti nuorten tutkijoiden alhaisia palkkoja, joiden seurauksena kyvykkäät opiskelijat eivät mielellään jääneet tutkimuksen pariin, vaan valmistuttuaan siirtyivät parempipalkkaisiin toimiin mm. liike-elämän palveluksessa. Tilaisuuden juhlaesitelmän piti professori Jaakko Keränen. Esitelmässään hän selvitti maatalousilmatieteen tehtäviä ja tutkimuksia maassamme mainiten mm. keskeisimpänä tutkimuskohteena olevan sadon riippuvuuden säätekijöistä.

\section{Vuodet $1950-59$}

Seura aloitti 1950-luvun vilkkaan toiminnan merkeissä. Kokouksissa kävijöiden määrät olivat kasvaneet välillä vallinneesta yleisökadosta. Kuulijakun- 
nan lukumäärä saavutti huippunsa, 108 henkeä, kun aiheena oli peltojen salaojitus. Kokouksia pidettiin yhdessä Helsingin eläinlääkäriseuran sekä Societas Biochemica-, Biophysica- ja Mikrobiologica Fennicae-seurojen kanssa. Ulkomaalaisia esitelmänpitäjiä kävi useita mm. Englannista, Saksasta, Norjasta ja Ruotsista.

Eräässä mielenkiintoisessa esitelmässään professori Nils Westermarck selvitti maataloustutkimuksen asemaa ja laajuutta Suomessa muihin pohjoismaihin verrattuna. Hän totesi, etteivät maataloustutkimuksellemme myönnetyt määrärahat yllä muiden pohjoismaiden tasolle. Laskettaessa määrärahoja suhteessa peltoalaan, johti Norja ylivoimaisesti, viimeisenä oli Suomi. Tämä meille epäedullinen suhde saattoi tietenkin johtua siitä, että taloudelliset resurssit meillä sodista ym. seikoista johtuen eivät olleet muiden pohjoismaiden tasolla. Maataloustutkimukselle ei Suomessa uhrattu yhtä paljon varoja kuin muissa Skandinavian maissa.

Suomessa eivät puutarha- eikä eläinlääketiede olleet tuolloin saaneet samaa huomiota osakseen kuin muissa pohjoismaissa. Hydrotekniikalla oli meillä sen sijaan hyvä asema. Niinikään taloustieteiden ja kotieläintalouden alalla oli tilanne Suomen kannalta verrattain tyydyttävä. Kasvinviljely oli erinomaisessa asemassa. Teknilliset tieteet, maatalouden koneoppi ja rakennusoppi näyttelivät vielä meillä hyvin vaatimatonta osaa. Todetaan myös, että Suomessa oli vähiten tutkijoita. Kuitenkin muihin pohjoismaihin verrattuna julkaistujen väitöskirjojen suuri lukumäärä, $44 \mathrm{kpl}$ vuosien $1931-51$ aikana, oli hyvänä osoituksena siitä, että meillä vaikeuksista huolimatta oli tehokkaasti ja johdonmukaisesti huolehdittu jälkikasvusta.

Suomalaisten tutkijoiden lukuisista ulkomaanmatkoista on osoituksena matkaesitelmien suuri määrä. Matkat suuntautuivat monien Euroopan maiden lisäksi mm. USA:han ja Afrikkaan.

Vuonna 1958 saatiin päätökseen Maatalouden sanakirjan painatustyö. Sen toimittaminen kesti 10 vuotta. Tämä teos käsittää yhteensä noin 19000 hakusanaa ja lisäksi englannin-, ruotsin- ja saksankieliset hakemistot. Maisteri Mali on työssään käyttänyt apunaan 91 kotimaista ja 238 ulkomaista asiantuntijaa. Toimittamisen taloudellisesta puolesta vastasi 28 lahjoittajaa. Näin on myös maatalouspuolelle saatu oma ammattisanasto, jonka tarpeellisuus on käytännössä jo todettu.

Esitelmien aiheista puheena olevana toimintajaksona voitaisiin vielä mainita mm. maatalouskoneiden yhteiskäyttöä koskevat kysymykset, siemen- ja kasvinsuojeluainekysymykset, kuivuus maatalouden ongelmana jne. Seuran sarjoissa julkaistuissa lukuisissa tutkimuksissaan kasvinviljelyn alaita professori Paatela selvitti monipuolisesti tärkeimpiä viljalajikkeitamme ja niiden viljelyalueita samoin kuin nurmikasvien viljelyä. Karjanjalostuksen tehostamistoimenpiteistä sonnien valinnan avulla ilmestyi julkaisuja. Suot ja niiden kasvusto kiinnostivat maanviljelyskemian- ja fysiikan tutkijoita. Soiden tutkimuksesta alkoi muodostua oma tieteenhaaransa - suotiede - , jonka alkukehitys suurelta osalta oli luettava professori Erkki Kivisen ansioksi. Tässä vain mutamia esimerkkejä eri alojen tutkimuskohteista. Professori A. I. Virtasen 60-vuotisjuhlajulkaisu, jossa on 19 eri tutkijan kirjoituksia, ansaitsee vielä maininnan. 
Pöytäkirjassa on myös tiedotus maatalous-metsätieteellisen tiedekunnan promootiojuhlasta 29.5. 1958, jossa monet seuran jäsenet vihittiin tohtoreiksi ja maistereiksi. Tämän jälkeen ei vastaavaa promootiota ole ollut maatalousmetsätieteellisessä tiedekunnassa.

Vuonna 1959 tuli puoli vuosisataa kuluneeksi seuran perustamisesta. Agronomien Yhdistyksen huoneistossa pidettiin juhlavastaanotto ja juhlakokoukseen kokoonnuttiin Metsätalolle. Tervehdyssanat lausui Seuran monivuotinen sihteeri professori Viljo Vainikainen. Juhlaesitelmän piti professori Erkki Kivinen aiheesta "Maataloustutkimuksenme kehityksestä ja saavutuksista." Professori Vainikainen on käytettävissä olevien muistiinpanojen mukaan kuvannut puheessaan seuran toinintaa. Hän on maininnut seuran kokoontuneen puolen vuosisadan aikana 271 kertaa. Kokouksissa oli esitelmöinyt 351 kotimaista seuran jäsentä tai ulkopuolista asiantuntijaa sekä 26 ulkomaista vierasta. Juhlaillallinen nautittiin Suomalaisella Klubilla 58 henkilön läsnäollessa. Juhlan kunniaksi ilmestyi Acta-sarjassa 407-sivuinen juhlanumero. Julkaisun painattamiseen oli saatu lukuisia lahjoituksia pankeilta ja maatalousalan liikkeiltä.

\section{Vuodel $1960-72$}

Tieteellinen julkaisutoiminta on kohdistunut 1960-luvun alkupuolella edelleen hyvin voimakkaasti kasvinviljelyyn ja maantutkimukseen. Niinpä tetraploidi puna-apila ja apilan siementuotanto olivat 1960-luvun alkupuolella huomattava tutkimuksen aihe. Maanmuokkauksen, kalkituksen, kastelun ym. vaikutuksia satoihin on selvitetty intensiivisesti. Väitöskirjatöinä on tutkittu $\mathrm{mm}$. suomalaisten ravitsemusta.

Kotieläinpuolella on saatu kuulla lukuisia pohjoismaisia esitelmöitsijöitä. Maanviljelystalouden aihepiiriin on sisältynyt $\mathrm{mm}$. sosiologisia näkökohtia. Niinpä ulkomaisten vierailijoiden välityksellä saatiin kuulla mm. kaupungin ja maaseudun suunnittelun sosiaalisista ongelmista sekä maatalouden liikaväestön ja teknillistymisen aiheuttamista rakennemuutoksista. Perheyrityksen tulevaisuutta pohdittiin saksalaisen vierailijan pitämän alustuksen pohjalta.

Maataloustutkimuksen kentän jatkuva laajeneminen ja erikoistuminen eri suuntiin sekä siitä johtuva jäsenjoukon harrastusten heterogeenisuus ovat vähitellen johtaneet siihen, että kokoukset ovat muodostuneet varsin suppeita piirejä kiinnostaviksi. Vuosikokous velvoittikin seuran johtoa toimimaan niin, että toiminta aktivoituisi ja katsoi samalla tarpeelliseksi seuran sääntöjen uusimisen. Tästä syystä aloitettiin vuonna 1965 seuran toiminnan tehostamistoimenpiteet.

Seuran toiminnan vilkastuttamiseksi tehtiin lukuisia ehdotuksia: kokousten aiheiden tulisi olla universaaleja, ehdotettiin seuran jakamista jaostoihin, johtokuntaa haluttiin laajentaa, puheenjohtajan toimiaikaa pidentää, johtokunnan jäsenten tulisi tasapuolisesti edustaa maataloustutkimuksen eri aloja, ja johtokunnan avuksi tulisi saada asiantuntijatoimikuntia. Informoinnin lisäämistä ja seuran toiminnan julkistamista pidettiin erikoisen välttämättömänä.

Johțokunta päättikin asettaa tuekseen kolme asiantuntijatoimikuntaa: kasvintuotannon, kotieläintuotannon sekä taloustieteellisen toimikunnan, joissa 
kussakin tulee olla $6-8$ jäsentä. Jäsenmäärää on pyritty lisäämään nuorilla maataloustutkimuksen ja neuvonnan piirissä työskentelevillä henkilöillä. Seuran tarkoitusperien kannalta pidetään tärkeänä neuvontajärjestöihin suuntautuvaa informaatiota.

Toimikuntien sisällä on pohdittu seuran toininnan svirittämistä» ajanmukaiselle tasolle ja jäseniä inspiroivaksi. Maatalousalan tutkimus, korkein opetus ja neuvonta olisi toimikuntien mielestä saatava entistä kiinteämpään keskinäiseen vuorovaikutukseen, sillä on havaittu, että nykytilanteen vallitessa tutkijoiden tiedoista jää suurin osa hyväksi käyttämättä. Esityksiä ja symposiumeja ehdotettiin pidettäväksi kaikkia kiinnostavista yleisaiheista, joilla olisi merkitystä kokonaisuuden kannalta.

Kotieläintuotantotoimikunta oli yksimielisesti sitä mieltä, että maassamme vallitsee hajanaisuus maataloustieteellisessä julkaisutoiminnassa. Keskitykseen tuli sen mielestä pyrkiä julkaisemalla vain yhtä kansainvälistä sarjaa, toinen sensijaan olisi varattava kotimaisia tiedonantoja varten.

Vastaavan kasvintuotantotoimikunnan ehdotukset olivat hyvin samantapaisia. Niissä kiinnitettiin huomiota mm. yhteistutkimusten hyödyllisyyteen. Nuorten tutkijain kehittämiseksi ehdotettiin kokoustilaisuuksia, joissa heille varattaisiin tilaisuus lyhyiden tiedonantojen esittämiseen. Detaljikysymysten esittämistä oli pyrittävä välttämään; ne jätettäköön erikoisseuroille.

Seuran toiminnassa ovat jatkuvasti olleet keskeisellä sijalla kokoukset ja niissä pidettävät alustukset keskusteluineen. Vuonna 1966 kuukausikokouksia hallitsivat symposiumit, joissa tarkasteltiin aina jotakin ajankohtaista aihetta. Aiheet liikkuivat laajoissa puitteissa. Esim. satotasomme kehittämisen edellytyksiä selviteltiin ilmaston, maalajin, lannoituksen, kasvivuorotuksen ja kasvinsuojelun kannalta, sekä perinnöllisen laadun parantamista pohdittiin metsän-, kasvin- ja kotieläinjalostuksen näkökulmasta. Yleisluontoisten aiheiden käsittelyssä pyrittiin entistä läheisempään yhteistoimintaan maatalousalan eri yhteisöjen kanssa. Kannattavuusnäkökohtien huomioonottamista pidettiin tärkeänä. Seuran toivottiin etsivän keinoja eräiden alojen, kuten koneja työtekniikan, tutkimus- ja opetusmahdollisuuksien parantamiseksi tiedekunnassamme.

Toukokuussa 1966 pidettiin kaikkien tieteellisten seurojen yhteinen kokous Säätytalolla. Siellä allekirjoitti 37 tieteellistä seuraa opetusministeriölle lähetetyn kirjelmän, jossa tieteellisten seurojen valtionapua pyydettiin lisäämään samassa suhteessa kuin jaettavia tutkimusapurahojakin.

Vuonna 1967 Maataloustieteellisen Seuran julkaisusarjojen yhdistämisajatus tuli jälleen ajankohtaiseksi oltuaan vireillä jo 1950-luvun lopulla. Yhdistetyn julkaisusarjan etuna olisi se, että kaikki Suomessa tehdyt maataloustieteelliset tutkimukset voitaisiin julkaista samassa sarjassa, mieluimmin aihepiirin mukaisissa omissa alasarjoissaan. Keskitetystä sarjasta voisivat kiinnostua entistä useammat ulkomaiset laitokset. Tämä lisäisi myös julkaisujen vaihtoa, johon kirjastomme sarjojen hankinta pääasiallisesti perustuu. Sarjalle ehdotettiin latinankielistä nimeä. Johtokunta halusi kuitenkin ennen muutosten tekoa selvittää, minkälaiset mahdollisuudet olisi saman tien yhdistää seuran molemmat julkaisusarjat sekä Maatalouden Tutkimuskeskuksen Annales Agriculturae-sarja. 
Helmikuun kokouksessa käsiteltiin kyseistä aihetta perinpohjaisesti. Asia kiinnosti siinä määrin koko tutkijakuntaa, että Metsätalolle oli kerääntynyt ennätysmäärä kuulijoita (115), ja puheenvuoroja käytettiin 29. Suuri enemmistö kannatti julkaisusarjojen yhdistämistä, kuten seuraavat puheenvuorot osoittavat: "Jos kaikki meillä tehdyt maataloudelliset tutkimukset julkaistaisiin samassa sarjassa, antaisi se myös muiden maiden tutkijoille aivan toisen kuvan maataloustutkimuksemme tasosta kuin nykyisen hajanaisen julkaisusysteemin vallitessa. Edes kotimaassa ei aina tiedetä, mitä kunkin omalta alalta on julkaistu.» Välihuomautuksena esitettiin, että merkittävä osa tutkimuksista kuitenkin tulee henkilökohtaisten kontaktien kautta ulkomaalaistenkin tietoon. Tässä yhteydessä tuli esille myös yhteispohjoismaisen sarjan perustamisajatus.

Seuran uudet säännöt hyväksyttiin vuosikokouksessa 1967. Aikaisemmat olivat jo 40 vuotta vanhat. Uusien sääntöjen mukaan puheenjohtajan ja varapuheenjohtajan toimikaudet ovat kaksivuotiset. Hallitusta täydennettiin viidennellä jäsenellä, jonka tuli toimia myös tiedotussihteerinä. Hallitus voi kutsua tuekseen aikaisemman käytännön mukaisesti asiantuntį̣atoimikuntia, jotka tekevät esityksiä seuran toiminnan kehittämiseksi, oman alan tutkimuksen ja korkeimman opetuksen edistämiseksi sekä seuran kokouksissa käsiteltäviksi aiheiksi.

Vuosina 1968-69 kehitettiin julkaisutoimintaa niin, että tutkimustulokset saataisiin mahdollisimman nopeasti palvelemaan käytännön tarkoituksia. Pohjoismaiden maataloustutkijain yhdistys teki ehdotuksen mahdollisuuksista jakautua Maataloustieteellisen seuran puitteissa PMY:n jaostoja vastaaviin osastoihin. Asiantuntijatoimikunnat pitivät vallitsevaa organisatiota kuitenkin nykyisissä olosuhteissa tarkoituksenmukaisena. Ehdotettu menettely vain hajoittaisi seuran nyt yhtenäisenä tapahtuvaa toimintaa.

Rahavarojen käytön tehostamiseksi vuonna 1970 ryhdyttiin mm. toimenpiteisiin painatuskustannusten alentamiseksi. Aikakauskirjassa julkaistavan artikkelin enimmäispituus määrättiin entisen 16 sivun asemesta 10 sivuksi. Pitemmistä artikkeleista joutui kirjoittaja itse maksamaan osan kustannuksista, vaikkakin seura on pyrkinyt mahdollisuuksiensa mukaan tässä suhteessa myöntämään avustusta.

Seuran julkaisutoimintaa häiritsee jatkuva varojen niukkuus, vaikkakin seura on yksityiskohtaisesti selvittänyt painatuskustannusten alentamismahdollisuudet ja myös toteuttanut niitä. Valtionavustus on pienentynyt usealla tuhannella markalla vuodesta 1968, mutta painatuskulut ovat sitä vastoin lisääntyneet ja julkaisutarve on kasvanut. Tämä on johtanut käytettävissä olevien varojen ja välttämättömästi julkaistavien tutkimusten epäsuhteeseen. Kirjoittajat ovat joutuneet odottamaan julkaisemista usein hyvinkin pitkään. Seuran puheenjohtajan, maanviljelysneuvos Hyppölän toimesta käännyttiin eräiden alan liikelaitosten ja järjestöjen puoleen pyytäen taloudellista tukea. Avustuksia saatiinkin siinä määrin, että päästiin pahimmasta kriisistä. Maataloustieteellinen Seura on hyvin kiitollinen kaikille lahjoittajille. Maatalousmetsätieteellinen toimikunta on viime vuosina osoittanut seuralle myös jonkin verran lisävaroja julkaisutoimintaan.

Seura on pyrkinyt suorittamaan väitöskirjojen painatuskustannuksista noin 
2/3. Rahavaikeuksiensa johdosta viime vuosina seura on kyennyt antamaan avustusta väitöskirjan kirjoittajille vain noin puolet painatuskuluista. Actasarjan kirjoittajat on velvoitettu tekemään itse kustannussopimuksen kirjapainon kanssa ja seura on suorittanut osan kustannuksista kirjoittajille käytettävissä olevien rahavarojen sallimissa rajoissa. Aikakauskirjan kirjoittajat ovat itse joutuneet maksamaan mm. kaikki eripainoksensa ja muut erikoiskustannukset.

Seuran hallitus on keräämiensä tilastotietojen perusteella osoittanut maataloustutkijoiden lukumäärän tuntuvasti lisääntyneen viime vuosina, ja tämä suuntaus näyttää jatkuvan. Tutkimusten aihepiiri on sen myötä laajentunut. Se ei enää käsittele pelkkää alkutuotantoa, vaan ulottuu elintarviketeknologian kautta ravitsemukseen saakka. Tämä on lisännyt tuntuvasti julkaisujen määrää. Todettakoon kuitenkin, että vain osa maataloustutkimuksen tuloksista julkaistaan seuran julkaisuissa.

Vuonna 1971 jäsenmaksut nostettiin 8 markasta 13 markkaan. Juoksevat menot. on pyritty peittämään jäsenmaksuista saaduilla tuloilla. Seuran julkaisuja varten laadittiin kirjoitusohjeet päätoimittaja, professori E. A. Jamalaisen toimesta. Maataloustieteellisen Seuran tavoitteena on päästä julkaisujen kirjoittamisessa perusteellisesta ja traditionaalisesta tyylistä asian ydinkohdat käsittelevään esitystyyliin, jota jo useissa maissa sovelletaan.

Seuran toiminta tehostui ja samalla monipuolistui 1960-luvun puolivälistä lähtien. Jäsenluku lisääntyi nuorilla tutkijoilla niin, että seitsemän viimeisen vuoden aikana on jäsenmäärä kasvanut 115 henkilöllä. Ensimmäisen kerran ylitettiin 400 vuoden 1972 lopulla.

Esitelmien aiheet ovat viime vuosina liikkuneet kotimaisissa, ajankohtaisissa ongelmissa.

Kotieläinpuolella on käsitelty mm. kotieläintuotannon ja -hoidon rationalisointia, erikoistunutta kotieläintuotantoa, markkinointia, säilörehun valmistusta, hivenaineita jne. Kasvintuotantoaiheista mainittakoon mm. kasvintuotannon kehitysnäkymät 1970-luvulla, rehuvalkuaistuotantoa ja rehuviljan laatua koskevat kysymykset. Kasvinjalostuksessa on tarkasteltu perinnöllisyystutkimuksen viimeisimpiä tuloksia ja ajankohtaisia tavoitteita jalostustyössä. Talouspuolelta voisi mainita $\mathrm{mm}$. naudanlihantuotannon taloudellisuuden, joka oli erään kokouksen teemana ja erittäin aktuellina maatalouspoliittisena kysymyksenä keräsi suuren kuulijakunnan. Tämän esityksen perusteella kävi hyvin selville miten tärkeätä olisi kotieläin- ja taloustutkijain välisen yhteistyön lisääminen ja kehittäminen. Viime aikojen eniten puheenaihetta aiheuttanut maatalouspoliittinen ongelma on ollut liikatuotanto, jonka järkevään selvittämiseen tarvitaan kaikkien maataloustutkijoiden myötävaikutusta.

Julkaisutoiminta on viimeisten 13 vuoden aikana ollut erittäin vilkasta. Väitöskirjoja on julkaistu 20 kappaletta, joista neljä on varsinaisen alkutuotannon ulkopuolelta. Acta-sarjan vihkoja on ilmestynyt tänä aikana numerot 95-129, yhteissivumäärän ollessa 3422. Professori Otto Vallelle omistettu juhlajulkaisu ilmestyi vuonna 1966. Professori Valle teki merkittävän elämäntyön maamme kasvinviljelyn ja siementuotannon kehittäjänä. Vuonna 1967 toimitettiin professori Lauri Paloheimon juhlajulkaisu, jossa on 14 tieteellistä kirjoitusta. Professori Paloheimo on huolehtinut 42 vuoden ajan kotieläintie- 
teen korkeimmasta opetuksesta Helsingin yliopistossa ja on näin ollen toiminut lähes koko nykyisen agronomikunnan kouluttajana. Vuonna 1971 ilmestyi Helsingin yliopiston rehtorin professori Erkki Kivisen juhlajulkaisu, jonka laatimiseen on osallistunut 22 kirjoittajaa. Professori Kivisen ansiot Helsingin yliopiston opettajana, vararehtorina ja rehtorina sekä hänen toimintansa korkeinta maatalousopetusta palvelevien Viikin laitosrakennusten aikaansaamisessa muodostavat tavallista mittavamman elämäntyön.

Maataloustieteellisen Seuran kahden julkaisusarjan - Acta Agralia Fennica ja Maataloustieteellinen Aikakauskirja - yhdistämisestä tehtiin päätös syksyllä 1972. Yhdistetyn sarjan nimenä päätettiin säilyttää Journal of the Scientific Agricultural Society of Finland - Maataloustieteellinen Aikakauskirja. Maataloustieteellinen Seura kustantaa lyhyempien artikkeleiden painatuksen. Uudistetun julkaisusarjan painoasua mutettiin samalla nykyaikaisemmaksi. Kirjoitusohjeissa päätettiin pääosin noudattaa Maatalouden tutkimuskeskuksen laatimaa "Tieteellisen julkaisun laadinnan opasta". Uudistettuna Maataloustieteellinen Aikakauskirja tulee olemaan yhtä laaja kuin tähänastiset sarjat yhteensä. Vuosikerta tulee sisältämään vähintään neljä tarvittaessa useampia vihkoja, yhteensä noin 500-600 sivua.

Suomen Maataloustieteellinen Seura on 60-vuotisen toimintansa aikana antanut merkittävän panoksensa maamme maatalouselinkeinon kehittämiseen. Se on tarjonnut puitteet tieteellisen tason keskustelulle kulloinkin ajankohtaisesta kysymyksestä käytännön maataloudessa. Tärkeitä ovat olleet myös seuran vaalimat ulkomaiset suhteet maatalousalan eturivin tiedemiehiin eri maissa. Useat maatalousalan johtavat suomalaiset henkilöt ovat toimineet seuran johtotehtävissä edistäen ja kehittäen seuran toimintaa.

Erityisen suuriarvoista on ollut Suomen Maataloustieteellisen Seuran työ tutkimusten saattamisessa julkaistuina opetuksen, neuvonnan ja jatkotutkimusten aineistoksi. Maatalouden kehitys on ollut erityisesti viime vuosina erittäin nopeata. Tutkimustarve on entisestään lisääntynyt ja aihepiiri on laajentunuț. Maataloustutkimusta lähelle sijoittuvat mm. ympäristönsuojelu, maankäytön ekonomia ja elintarviketieteet. Myöskin on katsottu olevan tarvetta kehitysmaaproblematiikkaa koskevan tutkimustoiminnan aloittamiseen maassamme.

Maataloustutkimuksella tulee erityisesti nyt maatalouden rakennemuutosten ollessa käynnissä olemaan keskeinen merkitys elinkeinon kehittämisessä. Suomen Maațaloustieteellisen Seuran aktiivista toimintaa tarvitaan tulevaisuudessakin. 


\section{Tilastotietoja}

\section{Kokoukset ja esitelmät}

Joulukuuhun mennessä 1934 seura oli pitänyt kaikkiaan 152 kokousta. Koko toimintansa aikana seura on kokoontunut 381 kertaa, keskimäärin 6-7 kertaa vuodessa. Seuraavassa ryhmittelyssä nähdään kokousten ja kokouksiin osallistuneiden määrän,jakautuminen ajanjaksottain.

Toimintajakso

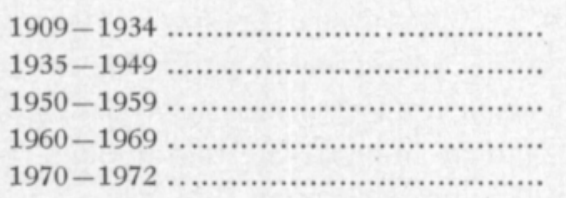

$\begin{array}{ccc}\text { Kokouksia } & \begin{array}{c}\text { Kokouksia } \\ \text { vuodessa } \\ \text { keskim. }\end{array} & \begin{array}{r}\text { Osallistujia } \\ \text { kokouksessa } \\ \text { keskim. }\end{array}\end{array}$

$\begin{array}{rll}152 & 6.1 & 21.4 \\ 64 & 4.6 & 37.7 \\ 69 & 6.9 & 38.0 \\ 75 & 7.5 & 40.0 \\ 21 & 7.0 & 43.0\end{array}$

Seuran kokouksissa pidettyjen esitelmien, tiedonantojen, opintomatkaselostusten, ulkomaisten luentovierailijoiden pitäminen esitelmien ja muistopuheiden lukumäärät vuosina 193572 jakautuvat seuraavasti:

\begin{tabular}{|c|c|c|c|c|}
\hline Toimintajakso & $\begin{array}{l}\text { Esitelmiä, } \\
\text { tiedonantoja }\end{array}$ & $\begin{array}{l}\text { Opintomatka- } \\
\text { selostuksia }\end{array}$ & $\begin{array}{c}\text { Ulkomaisten } \\
\text { tutkijoiden } \\
\text { esitelmiä }\end{array}$ & $\begin{array}{l}\text { Muisto- } \\
\text { puheita }\end{array}$ \\
\hline 1935-1949 „...................... & 68 & 3 & 13 & 7 \\
\hline $1950-1959 \quad \ldots \ldots \ldots \ldots \ldots \ldots \ldots \ldots \ldots \ldots \ldots \ldots \ldots \ldots$ & +6 & 11 & 25 & 8 \\
\hline $1960-1969 \quad \ldots \ldots \ldots \ldots \ldots \ldots \ldots \ldots \ldots \ldots \ldots \ldots \ldots$ & 111 & 2 & 29 & 6 \\
\hline $1970-1972 \quad \ldots \ldots \ldots \ldots \ldots \ldots \ldots \ldots \ldots \ldots \ldots \ldots \ldots$ & 53 & - & 1 & - \\
\hline 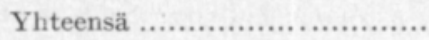 & 278 & 16 & 68 & 21 \\
\hline
\end{tabular}

Vuosien 1960-69 aikana pidettyjen esitelmien ja tiedonantojen suuri määrä johtuu lukuisista symposiumeista, joita järjestettiin 1960-luvulla. Muistopuheita on pidetty merkittäville seuran jäsenille sekä ulkumaisille kunnia- tai kirjeenvaihtajajäsenille. - Tulkoon mainituksi, että seuran 25-vuoden toimintajakson aikana vuosina 1909-34 oli kuultu kaikkiaan 239 esitelmää ja tiedonantoa sekä seitsemän muistopuhetta.

Vuosien 1935-72 aikana pidettyjen esitelmien aiheet jakautuvat aluittain seuraavasti:

\begin{tabular}{|c|c|c|c|c|}
\hline Toimintajaks & $\begin{array}{l}\text { Kasvin- } \\
\text { tuotanto }\end{array}$ & $\begin{array}{c}\text { Kotieläin- } \\
\text { talous }\end{array}$ & $\begin{array}{l}\text { Talous ja } \\
\text { tekniikka }\end{array}$ & $\begin{array}{l}\text { Maan- } \\
\text { tutkimus }\end{array}$ \\
\hline $1935-19+9$. & 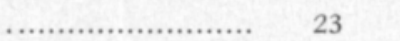 & 14 & 14 & 17 \\
\hline $1950-1959$. & n....................... & 6 & 3 & 12 \\
\hline $1960-1969$. & ……................ & 39 & 24 & 11 \\
\hline $1970-1972$. & ….................... & 18 & 15 & 6 \\
\hline Yhteensä ..... & 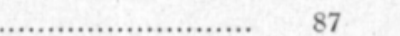 & 77 & 56 & 46 \\
\hline
\end{tabular}

kasvintuotanto: kasvinviljely, -jalostus, puutarhatiede, kasvipatologia, tuhoeläimet kotieläintalous: ruokinta, jalostus, fysiologia, eläiniääketiede, maitotalous, kalatalous talous ja tekniikka: maatila- ja metsätalous, maatalouspolitiikka, tyōtekniikka maantutkimus: maaperä, maanviljelyskemia ja -fysiikka, maatalousilmatiede

Joitakin esitelmiä on pidetty myös yllämainitun ryhmittelyn ulkopuolelta, esimerkiksi ihmisten ravitsemuksesta. 
Seuran julkaisuja on ilmestynyt seuraavasti: Abhandlungen der Agrikulturwissenschaftlichen Gesellschaft in Finnland vihot 1-13, yhteinen sivumäärä 1302. Suomen Maataloustieteellisen Seuran Julkaisuja - Meddelanden från Lantbruksvetenskapliga Samfundet i Finland, vihot 1-17, yhteinen sivuluku 2505. Edellä mainitut sarjat on yhdistetty vuonna 1928 Acta Agralia Fennica-nimiseksi, jota on ilmestynyt 129 numeroa yhteensă 19544 sivua vuoden 1973 maaliskuuhun mennessä, josta alkaen sarja sulautettiin Maataloustieteelliseen Aikakauskirjaan. Maataloustieteellistä Aikakauskirjaa ryhdyttiin julkaisemaan vuonna 1929, ja sitä on ilmestynyt vuosittain neljä numeroa. Aikakauskirjan kaikkien neljänkymmenenneljän vuosikerran yhteinen sivumäärä on hieman yli 10000 .

Julkaisujen päătoimittajana on toiminut professori B. Aarnio vuoteen 1937 asti ja siitä edelleen professori I. Poijärvi vuoteen 1957. Toimitussihteereinä ovat olleet professori E. Kivinen vuosina 1938-46 sekä tohtori P. Saarinen ja professori E. A. Jamalainen v. 1947 j48. Viime mainittu hoiti virkaa, kunnes nimitettiin päätoimittajaksi vuonna 1959. Professori Jamalainen toimi päätoimittajana aina huhtikuuhun 1972 asti, jolloin hän eläkkeelle siirtyneenä halusi luopua tehtävästä. Uudeksi påätoimittajaksi valittiin tohtori P. Elonen.

\section{Kirjasto ja julkaisujen vaihto}

Seuran kirjastoon alettiin kiinnittää huomiota v. 1921. Aluksi kirjasto sijaitsi Yliopiston maanviljelystaloudellisen laitoksen tiloissa. Kirjasto siirrettiin v. 1928 Valtion siementarkastuslaitokseen ja jälleen v. 1933 Yliopiston maanviljelystaloudelliseen laitokseen. Tällöin nidosten lukumäärän mainitaan ylittäneen $2500 \mathrm{kpl}$. Vuonna 1965 Seuran kirjasto muutti kaupungista yhdessä Maatalouskirjaston kanssa ensin tilapäissuojiin Viikkiin ja myöhemmin omaan kirjastosiipeensä.

Kirjastolla oli vuonna 1972345 vaihtopistettä kotimaassa ja ulkomailla, yhteensä 43 eri maassa. Seuran julkaisuista Acta Agralia Fennicaa lähetettiin 227 laitokselle ulkomailla ja 18 laitokselle kotimaassa. Vastaavasti Maataloustieteellistä Aikakauskirjaa lähetettiin 318 laitokselle ulkomailla ja 24 laitokselle kotimaassa. Vaihtona saatujen kotimaisten julkaisujen määrä oli 52 ja ulkomaisten 511, eli vaihdossa saatiin vuonna 1972 yhteensä 563 julkaisua.

Kirjastonhoitajina ovat toimineet: vuosina 1935-39 maisteri Marjatta Martola, 1939-41 maisteri Irma Poijärvi, 1941-70 maisteri Maj-Lis Tulander. Hänen jälkeensä on kirjastonhoitajana toiminut fil.lis. Harriet Rinne.

\section{Seuran toimihenkilöt}

Seuran toimihenkilöt vuosina 1935-72 selviävät oheisesta taulukosta. Professori V. Vainikainen ja maisteri A. Virtamo ovat molemmat toimineet yhtäjaksoisesti 26 vuotta, edellinen seuran sihteerinä ja jälkimmäinen rahastonhoitajana, ja ovat näin ollen tehneet suuriarvoisen työn Maataloustieteellisen Seuran hyväksi. Muista seuraa pitkään palvelleista todettakoon professori $\mathrm{O}$. Ringin toiminta rahastonhoitajana yhdeksän vuoden ajan.

Seuran toimihenkilōt vuosina $1935-72$

\begin{tabular}{llll} 
Toimintavuosi & & Puheenjohtaja & \multicolumn{1}{c}{ Sihteeri } \\
$1935-36$ & prof. & E. F. Simola & prof. J. O. Sauli \\
$1936-37$ & I. Poijärvi & O. Valle & tri E. Kivinen \\
$1937-38$ & K. T. Jutila & Lauri Paloheimo & V. Vainikainen \\
$1938-39$ & & &
\end{tabular}


Sihteeri

1940-41 tri

1941-42 prof,

1942-43

1943-44 tri

1944-45

1945-46 prof.

$1946-47$

1947-48

$1948-49$

1949-50

$1950-51$

$1951-52$

$1952-53$

1953-54

1954-55

1955-56

1956-57

1957-58

$1958-59$

1959-60

1960)-61

$1961-62$

1962-63

1963-64

1964-65

1965-66

1966-67

1967-68

$1968-69$

1969-70

1970-71

1971-72

$1972-73$
O. Jääskeläinen

A. E. Sandelin

O. Willandt

P. Kokkonen

U. Vartiovaara

E. Kivinen

P. Kaitera

E. A. Jamalainen

J. Vuorinen

T. Storgårds

N. Westermarck Onni Pohjakallio Antti Mäki

Vilho A. Pesola

M. Salonen

v. Kanervo

Juhani Paatela

P. Kajanoja

S. Suomela

M. Annila

P. Saarinen

A. Reinikainen

K. U. Pihkala

M. Sipilä

A. Jäntti

M. Sillanpää

E. Kivi

dos.

maanv.neuv. K. Hyppōlä

prof.
K. Hyppōlä

v. Brummer tri V. Vainikainen

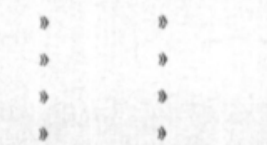

prof.

:

,

\section{?}

:

,
,
,
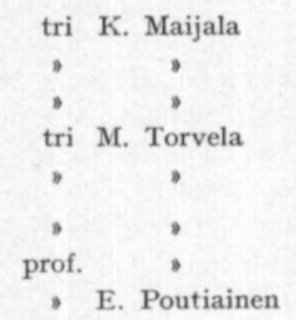

Rahastonhoitaja

maisteri A. Virtamo 
Suomen Maataloustieteellisen Seuran kotimaiset kunniajäsenet.

\begin{tabular}{|c|c|c|}
\hline Professori & A. Rindell ................ & $1921-1936$ \\
\hline 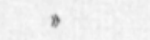 & G. Grotenfelt ............. & $1921-1922$ \\
\hline , & K. Enckell ................ & $1923-1937$ \\
\hline , & A. Osı. Kairamo ........ & $1934-1938$ \\
\hline Ylijohtaja & J. E. Sunila ............. & $1935-1936$ \\
\hline Professori & G. E. Bredenberg ...... & $1936-1955$ \\
\hline , & J. F. Liro ................. & $1943-1943$ \\
\hline , & A. I. Virtanen ............ & $1947-$ \\
\hline , & J. O. Sauli ................ & $1952-1957$ \\
\hline b & E. Kitunen ................. & $.1953-1955$ \\
\hline , & I. Poijärvi ................. & $1959-1970$ \\
\hline , & J. Keränen ............... & $1959-$ \\
\hline * & R. Pihkala ............... & $1959-$ \\
\hline , & K. T. Jutila ................ & $1964-1966$ \\
\hline , & E. Kivinen ................ & $1966-$ \\
\hline - & V. Vainikainen ........... & $1966-1971$ \\
\hline , & o. Valle ................... & $1966-1969$ \\
\hline - & V. A. Pesola .............. & $1967-$ \\
\hline - & Antti Mäki ................ & $1971-$ \\
\hline , & E. A. Jamalainen ...... & $1971-$ \\
\hline
\end{tabular}

Suomen Maataloustieteellisen Seuran nykyiset kirjeenvaihtajajäsenet.

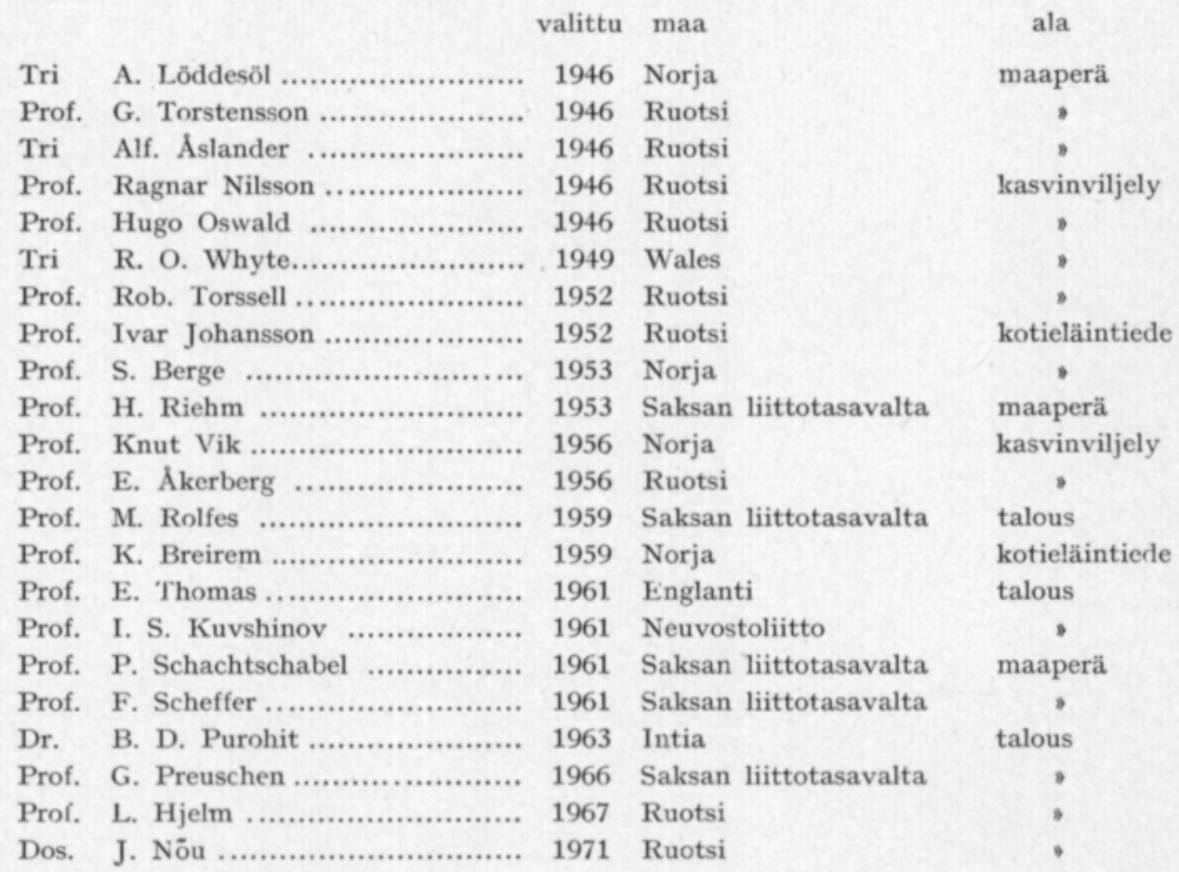

